\title{
Correction to: Optimal operational strategies of capital-constrained supply chain with logistics service and price dependent demand under 3PL financing service
}

\author{
Chuan Zhang $^{1}$ (1) $\cdot$ Ling-Wei Fan ${ }^{1} \cdot$ Yu-Xin Tian ${ }^{1}$
}

Published online: 26 November 2019

(C) Springer-Verlag GmbH Germany, part of Springer Nature 2019

\section{Correction to: Soft Computing}

https://doi.org/10.1007/s00500-019-04500-7

Page 5, Table 1, row 3, column 1: The text $c_{1}$ should read as $C_{l}$. The updated table has been copied below:
The original article has been corrected.

Publisher's Note Springer Nature remains neutral with regard to jurisdictional claims in published maps and institutional affiliations.

Table 1 Notation

\begin{tabular}{ll}
\hline Notation & Description \\
\hline$c$ & Unit manufacturing cost of the manufacturer \\
$C_{l}$ & Unit cost of the 3PL enterprise \\
$c_{\mathrm{s}}$ & Logistics service cost of the 3PL enterprise \\
$i_{\mathrm{r}}$ & Financing interest rate for the retailer \\
$i_{\mathrm{m}}$ & Financing interest rate for the manufacturer \\
$B_{\mathrm{r}}$ & Retailer's initial capital \\
$B_{\mathrm{m}}$ & Manufacturer's initial capital \\
$d$ & Basic market demand \\
$b$ & The sensitivity of the market demand to the retail price, referred to as the price sensitivity coefficient \\
$\theta$ & The sensitivity of the market demand to the logistics service level, referred to as the logistics service sensitivity coefficient \\
$\eta$ & Logistics service cost efficiency \\
$p$ & Retailer's unit retail price (decision variable) \\
$Q$ & Retailer's order quantity from the manufacturer (decision variable) \\
$w$ & Manufacturer's wholesale price for each unit of the product (decision variable) \\
$l$ & 3PL enterprise's unit logistics service price (decision variable) \\
$\zeta$ & 3PL enterprise's logistics service level (decision variable) \\
\hline
\end{tabular}

The original article can be found online at https:// doi.org/10.1007/s00500-019-04500-7.

Chuan Zhang

czhang@mail.neu.edu.cn

1 School of Business Administration, Northeastern University, Shenyang 110169, China 